\title{
EFFECTS OF VASODILATOR AGENTS ON SMOOTH MUSCLE CELLS OF THE CORONARY ARTERY OF THE PIG
}

\author{
T. ITOH, M. KAJIWARA, K. KITAMURA \& H. KURIYAMA \\ Department of Pharmacology, Faculty of Medicine, Kyushu University, Fukuoka 812, Japan
}

1 Effects of the vasodilator agents, papaverine, diltiazem, and sodium nitroprusside (SNP) on the electrical and mechanical activities of the smooth muscles of the coronary artery of the pig were compared.

2 At a concentration of $10^{-5} \mathrm{M}$, papaverine hyperpolarized and increased the ionic conductance of the membrane, SNP slightly hyperpolarized but diltiazem had no effect on the membrane potential and membrane ionic conductance.

3 At a concentration of $10^{-5} \mathrm{M}$, diltiazem abolished the spike evoked by outward current pulses in the presence of tetraethylammonium (TEA) $10 \mathrm{mM}$, while papaverine and SNP slightly reduced spike amplitude.

4 The $\mathrm{K}$-induced contraction produced by any given concentration of [K$]_{0}$ over $20.2 \mathrm{mM}$ was suppressed by diltiazem and SNP dose-dependently in concentrations greater than $10^{-6} \mathrm{M}$; higher concentrations of papaverine were required to suppress contraction.

5 The acetylcholine ( $\mathrm{ACh}$ )-induced contraction was suppressed by diltiazem and SNP at concentrations greater than $10^{-6} \mathrm{M}$ and by papaverine in concentrations over $10^{-5} \mathrm{M}$.

6 In saponin-treated skinned muscles, papaverine, diltiazem and SNP had no effect on the pCa-tension relationship, i.e. these agents had no effect on the Ca receptor of contractile proteins. Furthermore, the caffeine-induced contraction in skinned muscles (after Ca loading) was not affected by these agents, i.e. the mechanism of $\mathrm{Ca}$ release by caffeine in skinned muscles was not affected.

7 Chlorpromazine, an agent interacting with calmodulin, antagonized the contractile effect of calcium on skinned muscle fibres.

8 The results obtained are discussed in relation to spike and contraction generating mechanisms, i.e. the effects of these agents on $\mathrm{Ca}$ influx and $\mathrm{Ca}$ release from stored sites. The results indicated that at equimolar concentrations diltiazem suppressed the mechanical response in the coronary artery of the pig more than SNP or papaverine.

\section{Introduction}

Nitroglycerine (NG) produced no change in the membrane potential and membrane resistance at concentrations below $10^{-6} \mathrm{M}$, but at a concentration of $10^{-10} \mathrm{M}$ it produced nonselective suppression of the $\mathrm{K}$-induced, acetylcholine ( $\mathrm{ACh}$ )-induced or depolarization-induced contractions in smooth muscle cells and coronary arteries of the dog and the pig. The underlying mechanism of the action of NG is postulated to be immobilization of $\mathrm{Ca}$ from the storage site, mainly sarcoplasmic reticulum (Ito, Kitamura \& Kuriyama, 1979; 1980 a, b). In the rabbit pulmonary artery, sodium nitroprusside (SNP) hyperpolarized the membrane and reduced the membrane resistance. As a consequence, the contraction evoked by the various above stimulants was suppressed. Similar actions of SNP were also observed in the rabbit portal vein, i.e. SNP hyperpolarized the membrane, reduced the membrane resistance and suppressed spontaneous spike generation (Ito, Suzuki \& Kuriyama, 1978). This means that although NG and SNP are nitrite compounds the mechanisms by which they induce vasodilatation are different. The properties of smooth muscle cells in vascular tissues differ with the region and species. Therefore, to make a strict comparison of drug action in a vascular bed in vitro, the same species and same region should be used.

The present experiments were undertaken to compare the action of vasodilator agents on smooth muscle cells of the coronary artery of the pig. As vasodilator agents, SNP as a representative of nitrite compounds, diltiazem as a $\mathrm{Ca}$ blocking agent (Ca- 
antagonist or Ca channel blocker) and papaverine as a nonselective smooth muscle relaxant were used.

To compare the action of these vasodilator agents, we also examined their effects on the membrane and mechanical properties in intact muscles and also in skinned muscle cells prepared by treatment with saponin.

\section{Methods}

Adult pigs of either sex were killed in a local slaughter house; the hearts were placed in oxygenated Krebs solution at $15-18^{\circ} \mathrm{C}$ and when brought to our laboratory were still beating.

The large branches of the left and right coronary arteries were carefully dissected under a binocular microscope. The vessel diameter was about $3-5 \mathrm{~mm}$ at the Valsalva sinus and $1 \mathrm{~mm}$ at $50-60 \mathrm{~mm}$ distal to the sinus; tissue was taken mainly from the regions where the vessel diameter was between 0.5 and $1.0 \mathrm{~mm}$.

\section{Preparation}

For tension recording from normal and chemically skinned muscle cells, the vessel was carefully dissected by use of jeweller's forceps, opened in the longitudinal direction, and a circular strip, $0.1 \mathrm{~mm}$ in width and $0.5 \mathrm{~mm}$ in length, was prepared. The preparation was set up in a small chamber with a capacity of $0.9 \mathrm{ml}$ through which the test solution was superfused entering rapidly at one end and being removed by suction with a water pump at the other end. Both ends of the preparation were fixed between pieces of Scotch doublesided sticky tape (3M Co., St Paul, Minn.), and isometric tension was recorded with a strain gauge transducer (U-gauge, Shinko Co.).

\section{Recording of contractions from skinned muscles}

The tissue was superfused with modified Krebs solution of the following composition (mM): $\mathrm{Na}^{+}$137.4, $\mathrm{K}^{+}$5.9, $\mathrm{Mg}^{2+} 1.2, \mathrm{Ca}^{2+}$ 2.5, $\mathrm{Cl}^{-} 134.0, \mathrm{H}_{2} \mathrm{PO}_{4}^{-} 1.2$, $\mathrm{HCO}_{3}{ }^{-} 15.5$ and glucose 11.5. This was then replaced with a solution containing $\mathrm{K}^{+} 118 \mathrm{mM}$ in which the $\mathrm{NaCl}$ was replaced with $\mathrm{KCl}$ isotonically. After the $\mathrm{K}$-induced contraction was recorded, the solution was replaced with one containing $(\mathrm{mM}): \mathrm{KCl}$ 130 , Tris-maleate $20, \mathrm{MgCl}_{2} 5$, ATP 5 and EGTA 4 at $\mathrm{pH} 6.8$ (relaxing solution). Saponin treatment was then carried out by leaving the preparation for $20 \mathrm{~min}$ in the relaxing solution containing $50 \mu \mathrm{g} / \mathrm{ml}$ saponin (ICN: Ohtsuki, Mauzi, Palade \& Jamieson, 1978). The preparation was washed again with the same solution and left until the tension level became constant at about zero. Immediately before application of a $\mathrm{Ca}$ containing solution, the preparation was

a
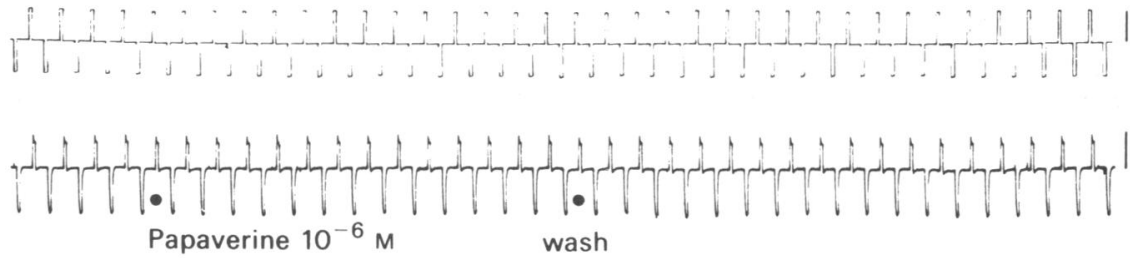

ii
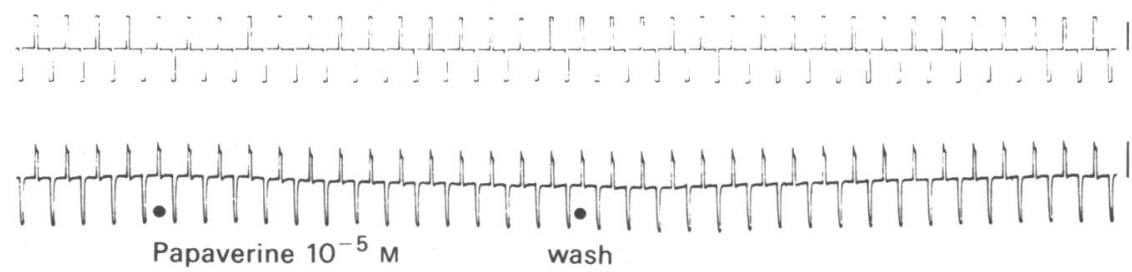

iii

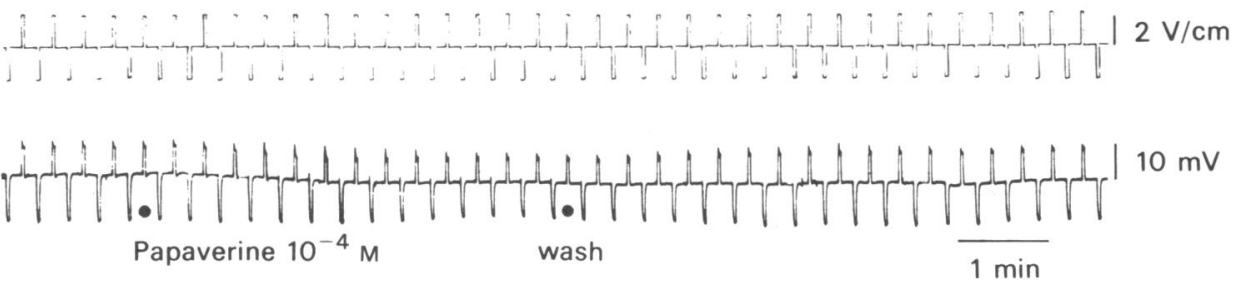

Figure 1 See legend opposite. 
b

i

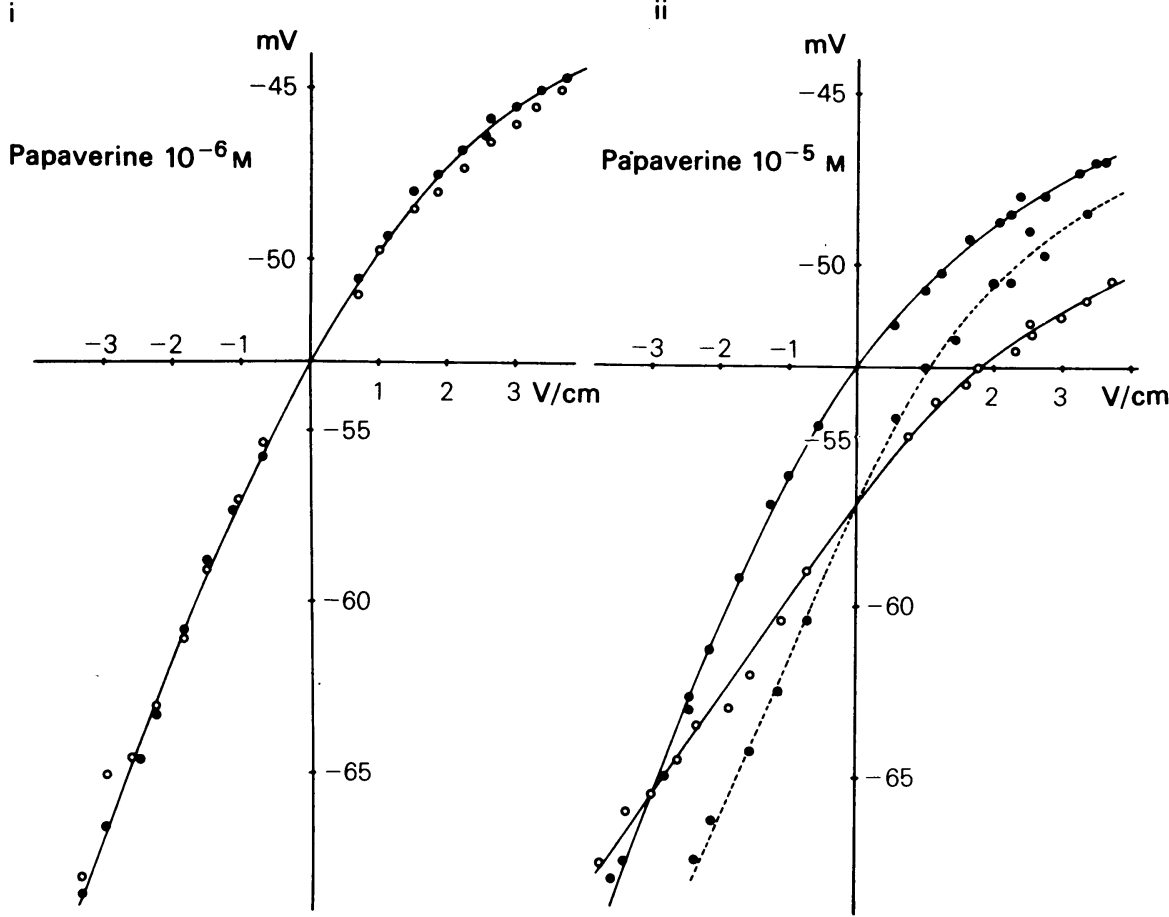

Figure 1 (a) Effects of papaverine on the membrane potential and resistance measured from the amplitude of electrotonic potentials produced by alternately applied inward and outward current pulses with a constant stimulus intensity: (i) $10^{-6} \mathrm{M}$ papaverine; (ii) $10^{-5} \mathrm{M}$ papaverine; (iii) $10^{-4} \mathrm{M}$ papaverine. Interval between dots is period of application of papaverine. Upper record: current monitor; lower record: potential change. (b) Effects of currentvoltage relationship observed in the presence or absence of papaverine: (i) application of $10^{-6} \mathrm{M}$ papaverine; (ii) $10^{-5} \mathrm{M}$ papaverine. The microelectrode was always inserted in the same cell throughout the experiment in both (i) and (ii). In (ii) the V-I relation was measured in Krebs solution $(\bullet)$ and in the presence of papaverine at the hyperpolarized level $(O)$. Subsequently in Krebs solution, the membrane potential was displaced to the hyperpolarized level by application of inward current to the level seen with papaverine, and the V-I relationship was measured $(\bullet$, with broken line).

superfused with the relaxing solution. These procedures were similar to those described by Saida \& Nonomura (1978) and Itoh, Kuriyama \& Suzuki (1981b).

To obtain a caffeine-induced contraction, the concentration of EGTA was reduced to $10^{-4} \mathrm{M}$ throughout the experiment. The $\mathrm{pH}$ of the procaine or caffeine containing solution was kept at 6.8 by addition of $\mathrm{KOH}$ instead of $\mathrm{KCl}$ isotonically.

Various $\mathrm{Ca}$ concentrations were prepared by adding appropriate amounts of $\mathrm{CaCl}_{2}$ to EGTA. The apparent binding constant of EGTA for Ca was considered to be $10^{6} \mathrm{M}^{-1}$, at $\mathrm{pH} 6.8$ (Harafuji \& Ogawa, 1980). To determine the binding constant of ATP for $\mathrm{Mg}$ at $\mathrm{pH} 6.8\left(4 \times 10^{3} \mathrm{M}^{-1}\right)$, we adopted the value calculated by Martell \& Schwarzenbach (1956), and referred to by Saida \& Nonomura (1978). The free Mg concentration was kept at $1 \mathrm{~mm}$.

\section{Recording of contractions from intact muscles}

For tension recording from intact muscle the same preparation was used as for the skinned muscle. This preparation was superfused with Krebs solution, and $118 \mathrm{~mm}[\mathrm{~K}]_{\mathrm{o}}$, ACh or caffeine was applied. For tension recording from the intact muscle during electrical stimulation, the same preparation as that used for electrical activity recording was used (see later). The mechanical response was recorded by a tension transducer (FD pick-up: Nihon Kohden) as described by Ito et al. $(1980 \mathrm{a}, \mathrm{b})$. Electrical stimulation was carried out by the partition stimulating method between two $\mathrm{Ag}-\mathrm{AgCl}_{2}$ electrodes (Abe \& Tomita, 1968).

\section{Electrical recording}

To observe changes in membrane potential, the ves- 
sel was carefully dissected under a binocular microscope, opened along its length, and a helical strip of $6-7 \mathrm{~mm}$ in length and $1-2 \mathrm{~mm}$ in width was prepared. Superfusion was carried out at a rate of $3 \mathrm{ml} / \mathrm{min}$ in a $2 \mathrm{ml}$ organ bath. Intracellular recording was with microelectrodes filled with $3 \mathrm{M} \mathrm{KCl}$ and having a resistance of $60-80 \mathrm{M} \Omega$. The microelectrode was inserted into the cell from the adventitial side. Changes in membrane resistance were recorded by the partition stimulating method (Abe \& Tomita, 1968). The membrane potential was expressed as the mean \pm s.d. The experimental procedures were the same as those described by Ito et al. (1980a, b).

The following drugs were used: acetylcholine chloride, sodium nitroprusside, papaverine, diltiazem (Tanabe), caffeine, ethylene-glycol-bis- $(\beta$ amino-ethylether)-N-N'-tetraacetic acid (EGTA; Dozin). Stock solutions of drugs were freshly prepared just before the experiments.

\section{Results}

\section{Effects of vasodilator agents on the membrane potential and spikes}

The resting membrane potential of smooth muscle cells of the pig coronary artery was $-53.4 \pm 2.3 \mathrm{mV}$ $(n=50)$. Application of papaverine in a concentration of over $10^{-5} \mathrm{M}$ hyperpolarized the membrane (in
$10^{-5} \mathrm{M},-56.8 \pm 1.9 \mathrm{mV}, \quad n=20, P<0.05$ and in $10^{-4} \mathrm{M},-57.8 \pm 1.6 \mathrm{mV}, n=20, P<0.05$ compared with the control). Thus in papaverine $10^{-4} \mathrm{M}$ and $10^{-5} \mathrm{M}$ the membrane potential had much the same value. On the other hand, diltiazem showed no effect on the membrane potential in the concentration range from $10^{-7} \mathrm{M}$ to $10^{-4} \mathrm{M}$ (in $10^{-4} \mathrm{M}$, $-53.8 \pm 2.9 \mathrm{mV}, n=15$ ), while SNP slightly hyperpolarized the membrane (in $10^{-4} \mathrm{M},-55.2 \pm 3.1 \mathrm{mV}$, $n=15)$. However, this was not statistically significant.

Effects of individual agents on the membrane potential and resistance were noted. As shown in Figure 1, the effects of papaverine on the membrane resistance measured with two different procedures were observed; application of constant current pulse before, during or after application of papaverine, or the relationship between the various applied current intensities and the amplitude of electrotonic potentials in the presence or absence of papaverine were investigated. In Figure 1a(i), constant intensity inward and outward current pulses were applied alternately in the presence of three different concentrations of papaverine $\left(10^{-6}-10^{-4} \mathrm{M}\right)$. The amplitude of the electrotonic potential evoked by outward current pulses was consistently smaller than that evoked by inward current pulses (a rectifying property), and strong outward current pulses produced a graded response. Application of papaverine $10^{-6} \mathrm{M}$ did not modify the membrane potential or the amplitude of electrotonic potential, but increasing the concentra-

a

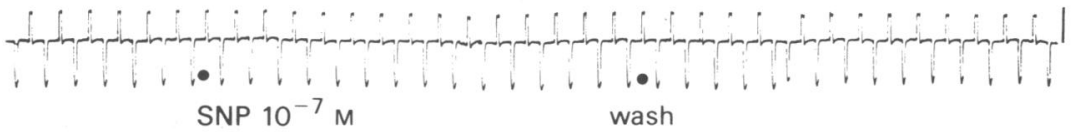

ii

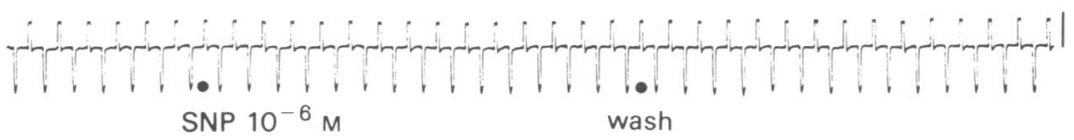

iii

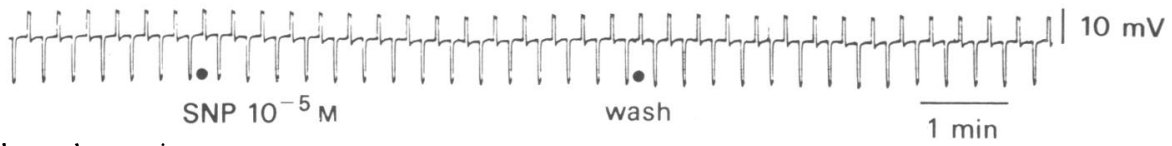

Figure 2 See legend opposite. 
b

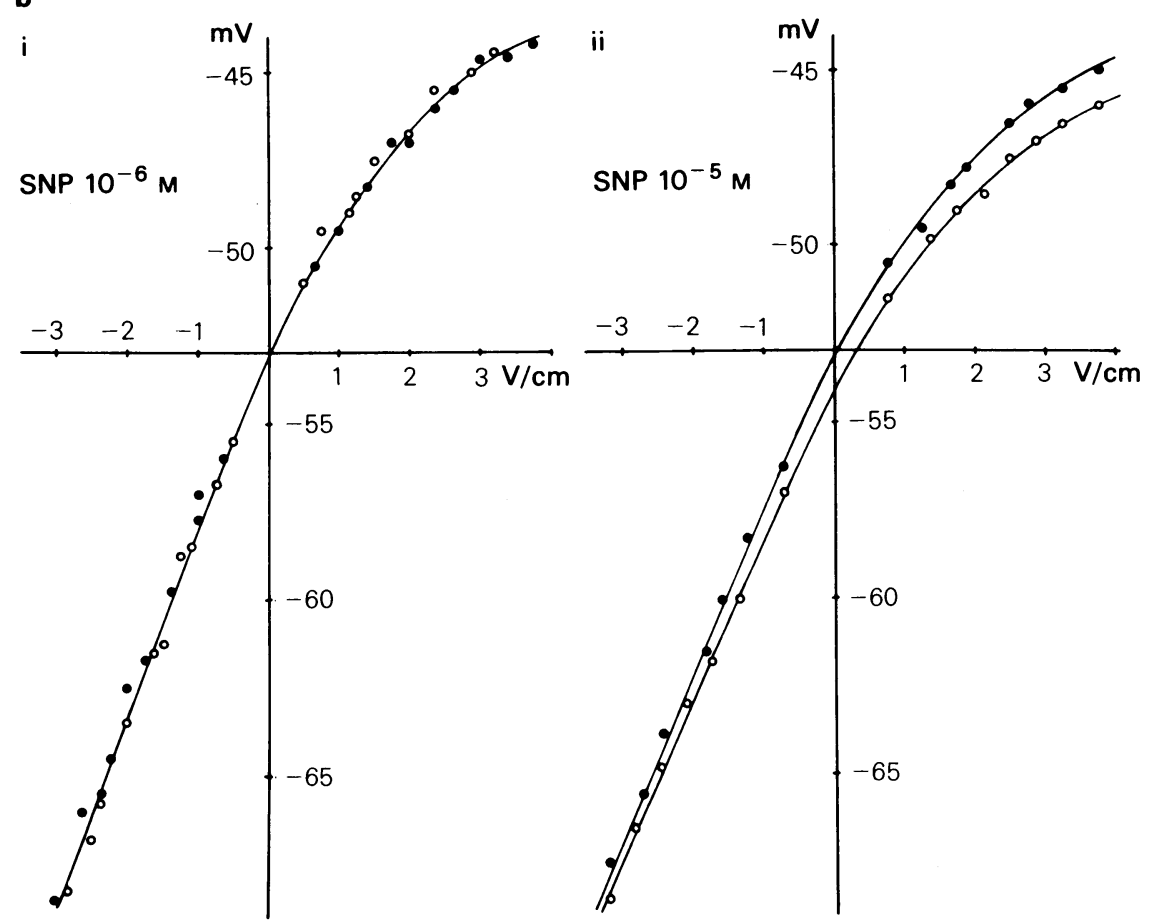

Figure 2 (a) Effects of sodium nitroprusside on the membrane potential and membrane resistance measured from the amplitude of electrotonic potentials. Inward and outward current pulses were alternately applied with the same intensity of current: (i) $10^{-7} \mathrm{M}$; (ii) $10^{-6} \mathrm{M}$; (iii) $10^{-5} \mathrm{M}$ sodium nitroprusside (SNP). Interval between dots indicates time of application of SNP. Upper record: current monitor; lower record: potential changes. (b) Effects of sodium nitroprusside on the current-voltage relationship: (i) $10^{-6} \mathrm{M}$ SNP; (ii) $10^{-5} \mathrm{M}$ SNP. ( $(\bullet)$ Control; (O) in the presence of SNP. Throughout a series of experiments, the microelectrode was inserted into the same cell at a distance of $0.1 \mathrm{~mm}$ from the stimulating electrode.

tion of papaverine hyperpolarized the membrane and reduced the amplitude of electrotonic potentials produced by both inward and outward current pulses (Figure 1a(ii) and (iii)). Figure $1 \mathrm{~b}$ shows the currentvoltage relationship of smooth muscles observed before and during application of $10^{-6} \mathrm{M}$ (i) or $10^{-5} \mathrm{M}$ papaverine (ii). The microelectrode was inserted at a distance of $0.1 \mathrm{~mm}$ from the stimulating electrode. During application of $10^{-6} \mathrm{M}$ papaverine, the current-voltage relationship was not affected as expected from the effects of this concentration on the membrane potential. During application of $10^{-5} \mathrm{M}$ papaverine, the membrane was hyperpolarized and the current-voltage relationship showed a reduction in the membrane resistance. To observe the effects of hyperpolarization on membrane resistance, the membrane potential in Krebs solution was displaced by the inward current to the level where the membrane was hyperpolarized by $10^{-5} \mathrm{M}$ papaverine, and the current-voltage relationship was again observed. At the same membrane potential level, papaverine reduced the membrane resistance measured by both inward and outward current pulses.
The effects of diltiazem on the membrane resistance were also measured from the amplitude of electrotonic potentials evoked by alternately applied inward and outward current pulses of constant intensity. In concentrations of $10^{-7} \mathrm{M}$ and $10^{-5} \mathrm{M}$ diltiazem, the membrane resistance was not affected. However, when the concentration was increased to $10^{-4} \mathrm{M}$, the membrane resistance was slightly reduced. The membrane resistance measured by outward current pulses was reduced to a greater extent than that measured by application of inward current pulses. These results confirmed the findings of Tajima, Kanda, Kitamura, Ito \& Kuriyama (1980) on the same tissue.

Figure 2a shows the effects of SNP on the membrane potential and resistance of smooth muscles of the porcine coronary artery. Three different concentrations of SNP $\left(10^{-7} \mathrm{M}, 10^{-6} \mathrm{M}\right.$ and $\left.10^{-5} \mathrm{M}\right)$ were applied. In concentrations over $10^{-6} \mathrm{M}, \mathrm{SNP}$ slightly hyperpolarized the membrane but the change in the amplitude of the electrotonic potential was undetectable. When the current-voltage relationships were compared in the presence or absence of SNP (Figure 
a

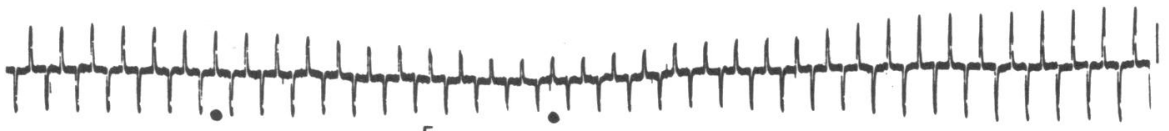
Papaverine $10^{-5} \mathrm{M}$ wash

ii

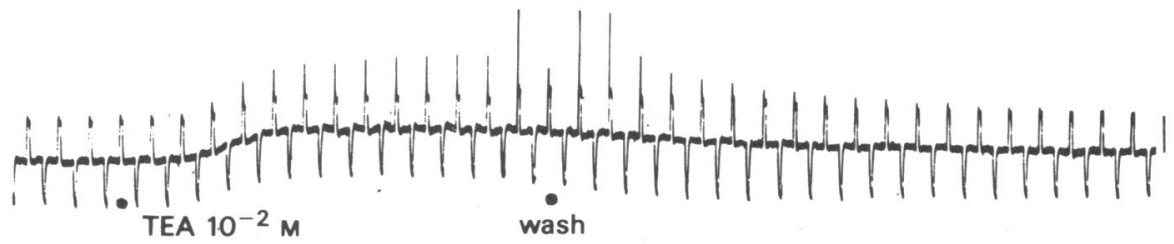

iii $11 \mathrm{~V} / \mathrm{cm}$

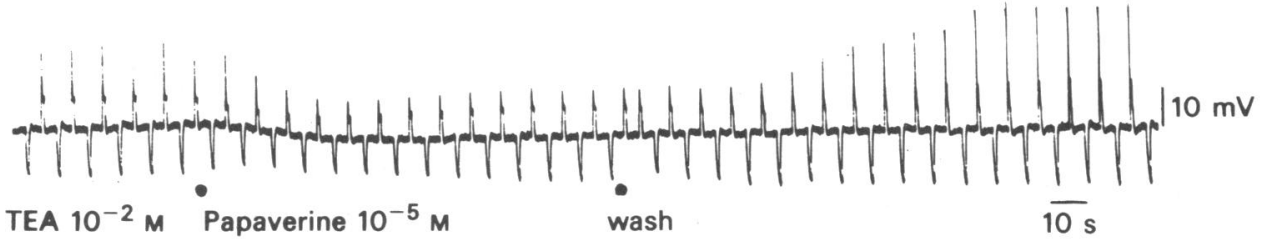

b

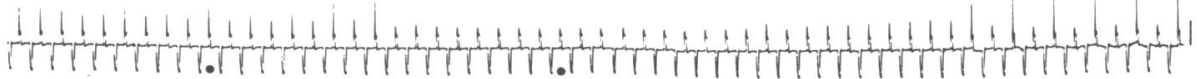
TEA $10^{-2} \mathrm{M}$ Diltiazem $10^{-6} \mathrm{M} \quad$ wash

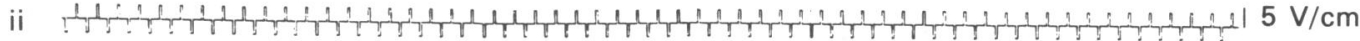

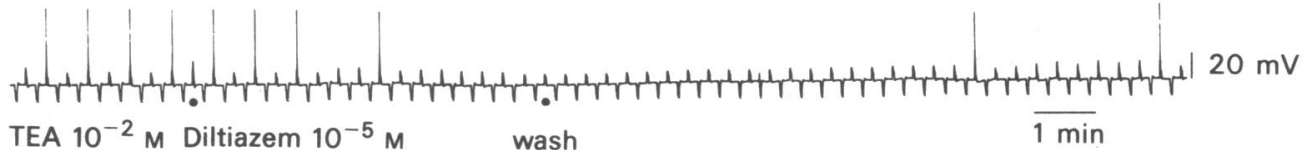

iii

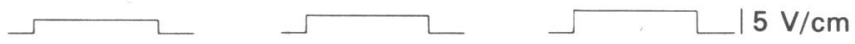

TEA $10^{-2} \mathrm{M}$
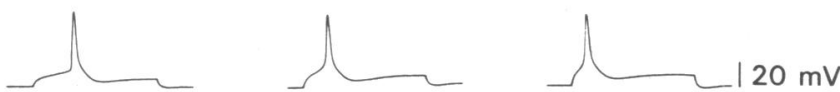

TEA $10^{-2} \mathrm{M}+$ Diltiazem $10^{-5} \mathrm{M}$

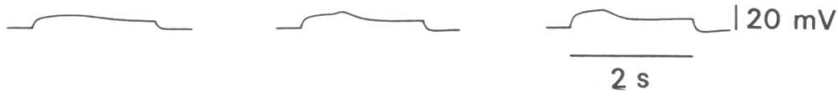

Figure 3 See legend opposite. 


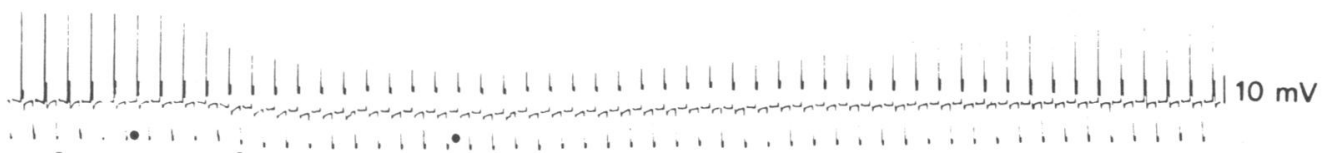

TEA $10^{-2} \mathrm{M}$ SNP $10^{-6} \mathrm{M}$ wash $\frac{1 \mathrm{~min}}{1}$

ii

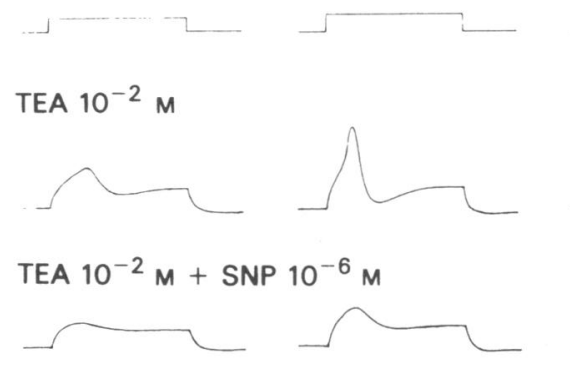

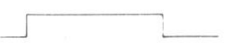
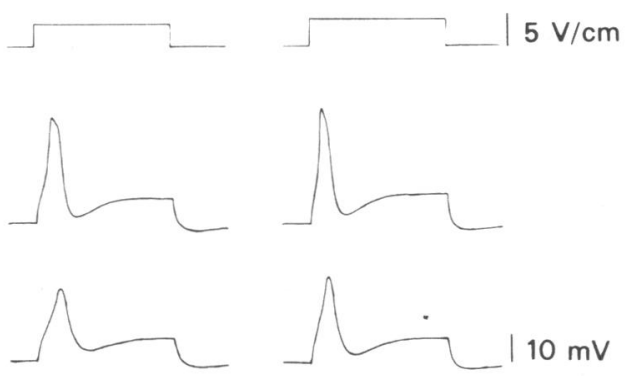

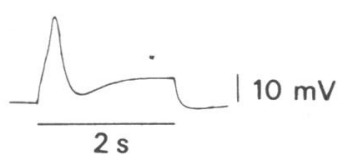

Figure 3 (a) Effects of papaverine on the spike evoked by outward current pulses in the presence of tetraethylammonium (TEA): (i) effects of papaverine $10^{-5} \mathrm{M}$; (ii) effects of TEA $(10 \mathrm{mM})$; (iii) effects of papaverine after pretreatment with TEA $(10 \mathrm{mM})$. Top record: current monitor; lower record: potential changes. Interval between dots indicates period of application of agents. (b) Effects of diltiazem on the spike evoked by outward current pulses in the presence of TEA (10 mM). In (i), $10^{-6} \mathrm{M}$ and in (ii) $10^{-5} \mathrm{M}$ diltiazem were applied (between dots). Intensity of current pulses was just above the threshold potential in order to evoke the spike in the presence of TEA. In (iii) effects of $10 \mathrm{mM}$ TEA and effects of diltiazem in the presence of TEA were recorded by application of three different intensities of outward current pulses. (c) Effects of $10^{-6} \mathrm{M}$ sodium nitroprusside on the spike evoked by outward current pulses in the presence of $10 \mathrm{mM}$ TEA: (i) effects of SNP $\left(10^{-6} \mathrm{M}\right)$ (between dots); (ii) four different intensities of outward current pulses were applied in the presence of TEA $(10 \mathrm{mM})$ and SNP (10 $\left.{ }^{-6} \mathrm{M}\right)$ with TEA (10 mM).

$2 b)$, the membrane resistance was slightly reduced in the presence of $10^{-5} \mathrm{M}$ SNP. In particular, the reduction was clear when the amplitude of the electrotonic potential produced by outward current pulses was compared with the control.

\section{Effects of vasodilator agents on the spike evoked by electrical stimulation in the presence of TEA}

The effects of papaverine, diltiazem and SNP were observed on the spike evoked by outward current pulses in the presence of $10^{-2} \mathrm{M}$ TEA. In Figure $3 \mathrm{a}$ (ii), effects of $10^{-2} \mathrm{M}$ TEA on the membrane potential and resistance were studied by applications of inward and outward current pulses. TEA depolarized the membrane and increased the membrane resistance and the outward current pulse produced a spike. The effect of TEA was reversible. After appli- cation of papaverine $\left(10^{-5} \mathrm{M}\right)$, the membrane depolarized by TEA was slightly hyperpolarized and the spike evoked by the outward current pulses was suppressed (Figure 3a(iii)). However, this suppression could not be attributed to hyperpolarization of the membrane, because when the membrane potential in the presence of papaverine was displaced to the control level, a graded response and not a spike was still produced. Another interesting finding was that after returning to Krebs solution containing $10 \mathrm{~mm}$ TEA but no papaverine, the amplitude of the spike was enhanced transiently compared with that observed before application of papaverine (Figure $3 a($ iii)).

Diltiazem also suppressed the spike evoked by outward current pulses in the presence of $10 \mathrm{mM}$ TEA (Figure $3 \mathrm{~b}$ ). In the presence of $10 \mathrm{~mm}$ TEA, when threshold intensity of outward current pulses 
required to produce a spike was applied, a spike was evoked with every other stimulation. Application of diltiazem $10^{-6} \mathrm{M}$ suppressed the spike and only graded responses remained (Figure $3 b(i)$ ), while application of $10^{-5} \mathrm{M}$ diltiazem completely suppressed both spikes and graded responses evoked by outward current pulses. The membrane resistance measured from the amplitude of the electrotonic potential produced by inward current pulses was not affected by application of $10^{-6} \mathrm{M}$ or $10^{-5} \mathrm{M}$ diltiazem (Figure $3 b$ (i) and (ii)). Figure $3 b$ (iii) shows the effects of diltiazem $\left(10^{-5} \mathrm{M}\right)$ on the membrane activity recorded with three different intensities of outward current pulses (above the threshold intensity) in the presence of $10 \mathrm{mM}$ TEA together with expanded time-base recordings.

Figure 3c shows the effects of SNP on the spike evoked by outward current pulses in the presence of $10 \mathrm{~mm}$ TEA. To evoke the spike, we used outward current intensity somewhat greater than the threshold required to produce a spike. As a consequence, the spike was consistently evoked by outward current pulses. Application of $10^{-6} \mathrm{M}$ SNP or even $10^{-5} \mathrm{M}$ reduced the amplitude of the spike but did not abolish it.

These results indicate that papaverine, diltiazem and SNP suppressed spike generation in the order diltiazem $>$ SNP $>$ papaverine, with equimolar concentrations, while on membrane conductance, the potency of these agents in increasing the ionic conductance of membranes was as follows: papaverine $>$ SNP $>$ diltiazem. This means that changes in the passive ionic permeability of smooth muscles of the coronary artery are not a prerequisite for the suppression of spike generation.

\section{Effects of vasodilator agents on the mechanical response of intact muscles}

In the coronary artery of the pig, excess $[\mathrm{K}]_{\mathrm{o}}, \mathrm{ACh}$ and caffeine produced contraction by different mechanisms; excess $[\mathrm{K}]_{\mathrm{o}}$ increased Ca-influx, ACh activated the muscarinic receptor distributed on the plasma membrane which triggered the release of the stored $\mathrm{Ca}$, and caffeine released the stored $\mathrm{Ca}$ by a direct action on the sarcoplasmic reticulum (Ito et al., 1980a; Itoh, Kajiwara, Kitamura \& Kuriyama 1981a). The effects of papaverine, diltiazem and SNP on the contraction evoked by excess $[\mathrm{K}]_{o}$ and $\mathrm{ACh}$ were also observed.

Figure 4a shows the effects of papaverine, Figure $4 b$ the effects of SNP and Figure 4c the effects of diltiazem on the $\mathrm{K}^{+}$-induced (i) and $\mathrm{ACh}$-induced (ii) contractions. In this series of experiments, the contraction evoked by $118 \mathrm{mM}[\mathrm{K}]_{\mathrm{o}}$ was registered as a relative tension of 1.0 . When concentrations of $10^{-6} \mathrm{M}$ to $10^{-4} \mathrm{M}$ papaverine were applied, the $\mathrm{K}$ - induced contraction was suppressed only by $10^{-4} \mathrm{M}$ papaverine. SNP suppressed the $\mathrm{K}$-induced contraction at concentrations over $10^{-5} \mathrm{M}$. The effects of diltiazem have been described by Tajima et al. (1980), who showed that at $10^{-6} \mathrm{M}$ it suppressed the $\mathrm{K}$-induced contraction $(P<0.05$ in the presence of over $\left.39.2 \mathrm{mM}[\mathrm{K}]_{\mathrm{o}}\right)$. The inhibitory effects of equimolar concentrations of these agents on the $\mathrm{K}$-induced contraction were in the order of diltiazem $>$ SNP $>$ papaverine.

On the other hand, these 3 agents consistently suppressed the ACh-induced-contractions at concentrations of over $10^{-6} \mathrm{M}$ (SNP and diltiazem) or $10^{-5} \mathrm{M}$ (papaverine) (Figure $4 \mathrm{a}(\mathrm{ii}), \mathrm{b}(\mathrm{ii}), \mathrm{c}(\mathrm{ii})$ ); $10^{-5} \mathrm{M}$ papaverine and SNP reduced the amplitude of the control contraction evoked by $10^{-4} \mathrm{M} \mathrm{ACh}$ by approximately $50 \%$. The inhibitory effects on the ACh-induced contractions (with equimolar concentrations) were in the order: diltiazem $=$ SNP > papaverine. When $10^{-4} \mathrm{M}$ papaverine was applied to the tissue, the $\mathrm{ACh}$-induced and $\mathrm{K}$-induced contractions were both greatly reduced. However, the inhibitory action of papaverine on $\mathrm{K}$-induced mechanical responses increased sharply between $10^{-5} \mathrm{M}$ and $10^{-4} \mathrm{M}$, and after application of $10^{-4} \mathrm{M}$ restoration of the contractile response was not always possible. However, with diltiazem or SNP, the inhibitory action on the contraction was dose-dependent.

The effects of papaverine, diltiazem and SNP on the $\mathrm{ACh}$-induced contraction in Ca-free (EGTA $2 \mathrm{mM}$ containing) solution were investigated. In Cafree solution the $\mathrm{ACh}$-induced contraction was slightly reduced within $3 \mathrm{~min}$ and the amplitude of contraction remained much the same (up to $15 \mathrm{~min}$ in Figure 5a). The amplitude of contraction evoked by calcium-containing $118 \mathrm{mM}[\mathrm{K}]_{\mathrm{o}}$ was considered as a relative tension of 1.0. Therefore, the $\mathrm{ACh}$-induced contraction evoked by $10^{-5} \mathrm{M} \mathrm{ACh}$ was greater than 1.0. In Figure 5b, the effects of various concentrations of papaverine, diltiazem and SNP on the $\mathrm{ACh}$-induced contraction $\left(10^{-5} \mathrm{M}\right)$ in Ca-free solution are shown. Concentrations of papaverine over $10^{-5} \mathrm{M}$ and diltiazem or SNP over $10^{-6} \mathrm{M}$ suppressed the ACh-induced contraction. Application of $10^{-4} \mathrm{M}$ papaverine reduced the $\mathrm{ACh}$-induced contraction to a greater extent than the same concentration of diltiazem or SNP. These effects of vasodilator agents on the $\mathrm{ACh}$-induced contraction in $\mathrm{Ca}$-free solution were similar to those observed in Krebs solution.

\section{Effects of the vasodilator agents on skinned muscles}

The relationships between $\mathrm{pCa}$ and tension recorded from skinned muscles of the pig coronary artery were investigated in the presence of vasodilator agents. Before preparing these muscles, the amplitude of contraction evoked by $118 \mathrm{mM}[\mathrm{K}]_{\mathrm{o}}$ was registered 

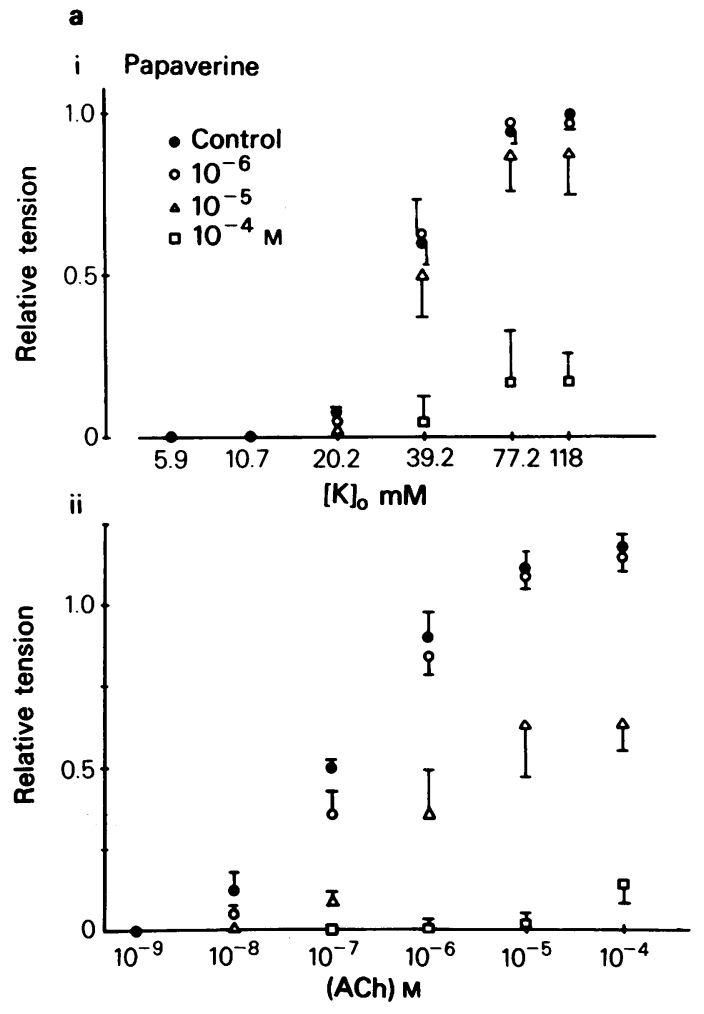

b
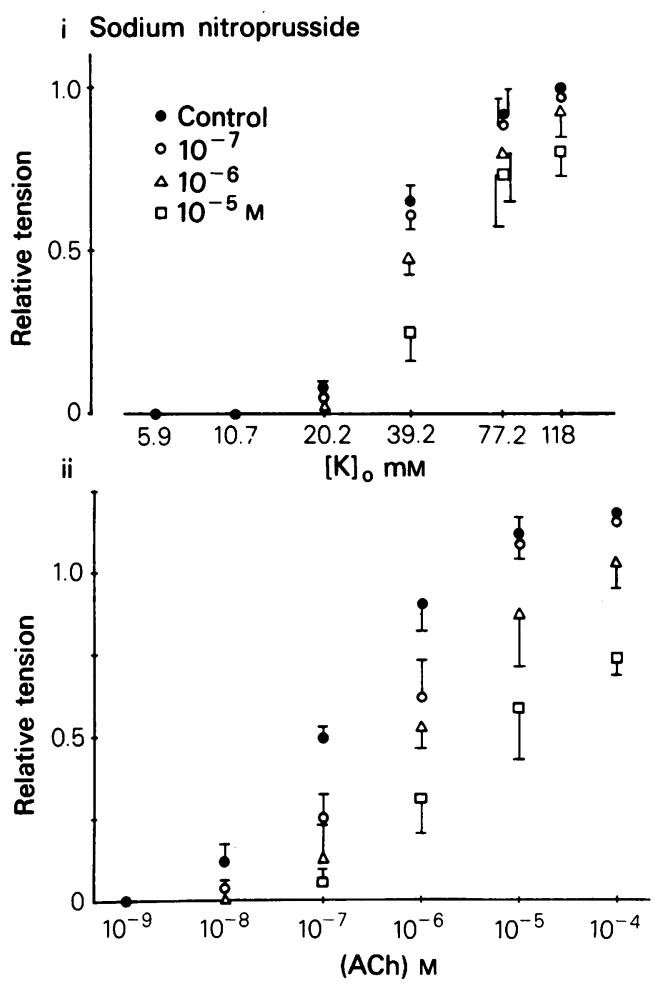

i Diltiazem
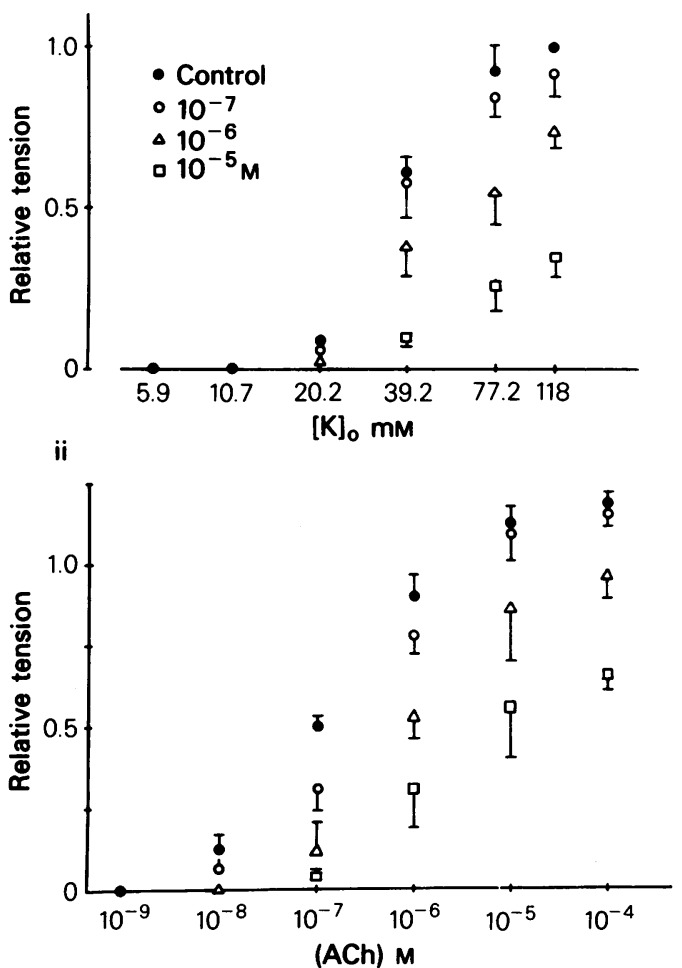

Figure 4 (a) Effects of papaverine on the $K^{+}$-induced contraction (i) and acetylcholine-induced contraction (ii). The tension was expressed as relative to the contraction evoked by $118 \mathrm{mM}[\mathrm{K}]_{\mathrm{o}}$ (considered as 1.0 ) in both the $\mathrm{K}$ - and acetylcholine ( $\mathrm{ACh}$ )-induced contractions. Concentrations of papaverine are indicated in the figure by a symbol as shown in the key. (b) Effects of sodium nitroprusside on the $\mathrm{K}^{+}$-induced contraction (i) and the ACh-induced contraction (ii). (c) Effects of diltiazem on the $\mathrm{K}^{+}$-induced (i) and the $\mathrm{ACh}$-induced (ii) contractions. Details of (b) and (c) as in (a).

(Figure 6a). The tissue was then rinsed with the relaxing solution and saponin $(50 \mu \mathrm{g} / \mathrm{ml})$ was applied for about $20 \mathrm{~min}$, as described in Methods. One criterion for the completion of skinning was that the maximum amplitude of the contraction evoked by $\mathrm{Ca}$ (usually over $10^{-5} \mathrm{M}$ free $\mathrm{Ca}$ ) was larger than the maximum amplitude of contraction evoked by $\mathrm{ACh}$ $\left(10^{-5} \mathrm{M}\right)$ or $118 \mathrm{mM}[\mathrm{K}]_{\mathrm{o}}$ in the intact tissue. To produce the contraction, increasing concentrations of Ca were applied cumulatively (Figure 6b). After the contraction reached a steady level, $10^{-4} \mathrm{M}$ papaverine, diltiazem or SNP was applied in the presence of various concentrations of free $\mathrm{Ca}$ $\left(3 \times 10^{-7} \mathrm{M}-10^{-5} \mathrm{M}\right)$. These agents had no effects on the amplitude of contraction evoked by any given concentration of $\mathrm{Ca}$. In Figure $6 \mathrm{c}$, the relationship 


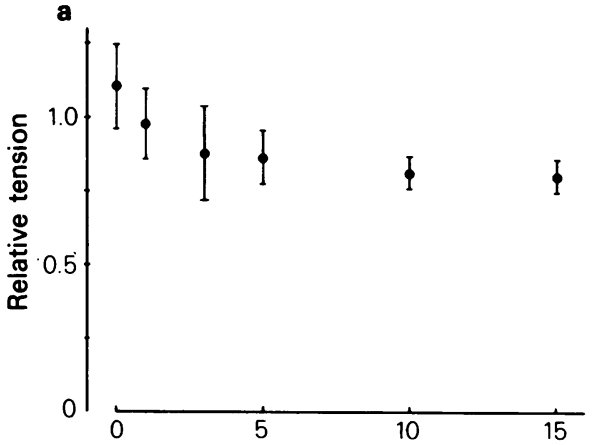

Exposure time in $\mathrm{Ca}$-free solution (min)

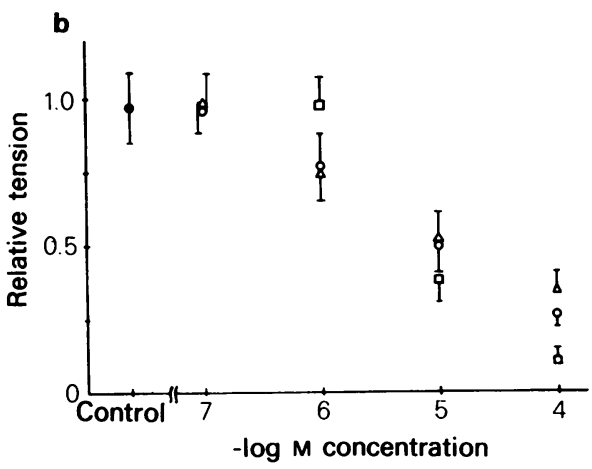

Figure 5 (a) Effects of Ca-free ( 2 mM EGTA containing) solution on the acetylcholine ( $\mathrm{ACh}$ )-induced contraction $\left(10^{-5} \mathrm{M} \mathrm{ACh}\right) ; n=4$; (b) Effects of papaverine $(\square)$, diltiazem $(\triangle)$ and sodium nitroprusside $(O)$ on the ACh-induced contraction in Ca-free EGTA containing solution; $(\Theta)=$ control. ACh $10^{-5} \mathrm{M}$ was applied to produce the contraction.

between pCa-tension is shown in the presence or absence of various vasodilator agents. Papaverine, diltiazem and SNP had no effect on the above relationship. These results indicate that the $\mathrm{Ca}$ receptors of contractile protein were not affected by application of these three agents. These findings were similar to those obtained with caffeine $(5 \mathrm{~mm})$ or procaine $(5 \mathrm{~mm})$ on the pCa-tension relationship of skinned muscles of the pig coronary artery (Itoh et al., 1981a).

To determine whether these agents actually had no effect on the above relationship or whether their ineffectiveness was due to inadequate saponin treatment, the effects of chlorpromazine, a calmodulin interacting agent (Hidaka, Yamaki, Naka, Tanaka, Hayashi \& Kobayashi, 1980), was assessed. Figure 7 shows the effects of chlorpromazine $(\mathrm{Cpz})$ on the $10^{-6} \mathrm{M} \mathrm{Ca}$-induced contraction in skinned muscles. As a control, $118 \mathrm{mM}[\mathrm{K}]_{\mathrm{o}}$-induced contraction was observed in the intact tissue. In fact, papaverine a
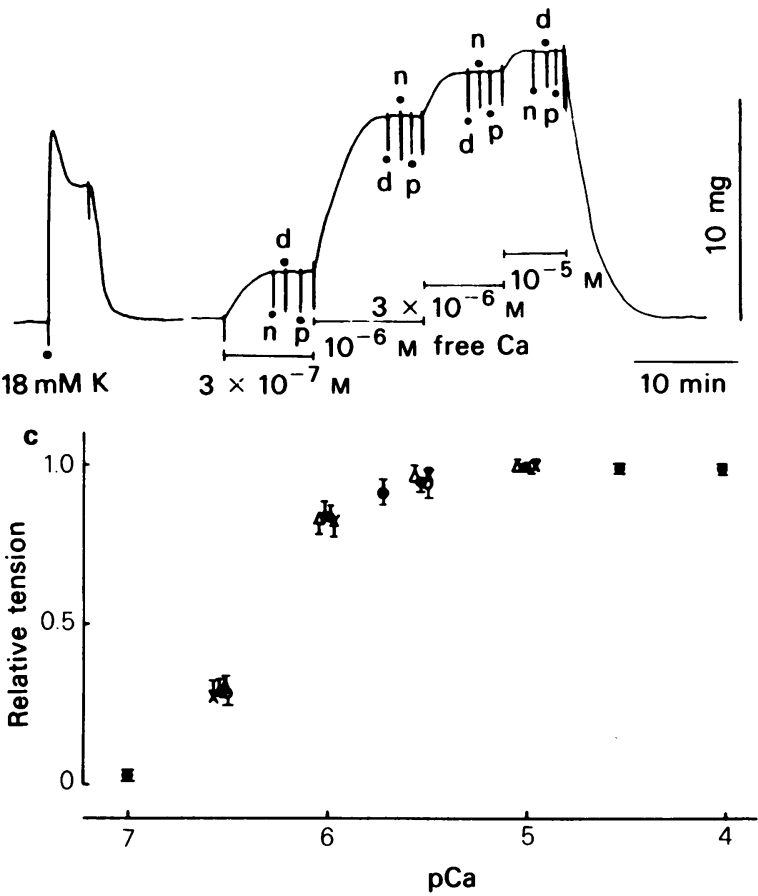

Figure 6 Effects of papaverine (p), diltiazem (d) and sodium nitroprusside $(n)$ on the contraction evoked in the saponin-treated skinned muscles. In (a) the contraction evoked by $118 \mathrm{mM}[\mathrm{K}]_{\mathrm{o}}$ in intact tissue is shown. In (b) after skinning the tissue, four different concentrations of free $\mathrm{Ca}$ were applied. Sodium nitroprusside, diltiazem and papaverine were applied after the contraction evoked by free $\mathrm{Ca}$ had reached a steady level. Vertical deflections in (b) are artifacts induced by rapid replacement of test solutions. In (c) pCa-tension relationship observed in the relaxing solution (control, 0 ). Papaverine $10^{-4} \mathrm{M}(\mathrm{X})$; diltiazem $10^{-4} \mathrm{M}(\mathrm{O})$ or sodium nitroprusside $10^{-4} \mathrm{M}(\triangle)$ was added in the relaxing solution containing various concentrations of free $\mathrm{Ca}$.

$\left(10^{-4} \mathrm{M}\right)$ had no effect on the Ca-induced contraction, while $\mathrm{Cpz}\left(10^{-4} \mathrm{M}\right)$ suppressed the contraction evoked by $10^{-6} \mathrm{M} \mathrm{Ca}$.

The effects of $10^{-4} \mathrm{M}$ papaverine, diltiazem or SNP on the caffeine-induced contraction in skinned muscles after Ca loading were investigated by the following procedures: In the intact muscle, $118 \mathrm{~mm}[\mathrm{~K}]_{0}$ was applied to evoke a contraction as the control. After the muscle had been treated with saponin in the relaxing solution, $10^{-6} \mathrm{M} C \mathrm{C}$ with $10^{-4} \mathrm{M}$ EGTA was applied for $3 \mathrm{~min}$ (procedure 1), then the preparation was rinsed with Ca-free and $10^{-4} \mathrm{M}$ EGTA solution for $3 \mathrm{~min}$ in the presence of various vasodilator agents (procedure 2), after which $5 \mathrm{~mm}$ caffeine with various vasodilator agents was applied (procedure 

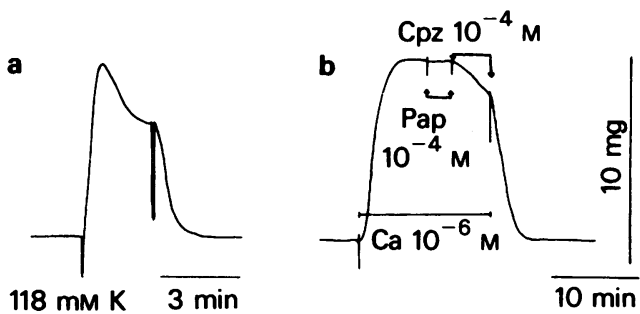

Figure 7 Effects of papaverine and chlorpromazine on the Ca-induced contraction $\left(10^{-6} \mathrm{M}\right.$ free $\left.\mathrm{Ca}\right)$ in skinned muscles. As a control, $118 \mathrm{mM}[\mathrm{K}]_{\mathrm{o}}$-induced contraction was registered in intact muscle tissue (a). After skinning the muscles, $10^{-6} \mathrm{M}$ free $\mathrm{Ca}$ was applied (b). Papaverine $\left(\mathrm{Pap}, 10^{-4} \mathrm{M}\right)$ and chlorpromazine $\left(\mathrm{Cpz} 10^{-4} \mathrm{M}\right)$ were successively applied to the tissue. The sharp vertical deflections of the trace are washing artifacts.

$3)$; i.e. the vasodilator agent was applied throughout procedures 2 and 3 . A typical example of a control experiment is shown in Figure 8b. In this figure, (a), (b) and (c) were recorded from the same preparation, and (d-h) were from another preparation. Application of $10^{-4} \mathrm{M}$ papaverine, diltiazem or SNP had no effect on the Ca releasing mechanism activated by caffeine in skinned muscles. The amplitude of caffeine-induced contractions produced by procedure 3 in comparison to that observed in the absence or presence of vasodilator agents was compared statistically. The contraction evoked by $5 \mathrm{~mm}$ caffeine in the absence of the agent was taken as $100 \%$. The concentration of these agents was $10^{-4} \mathrm{M}$ and individual agents were applied during procedures 2 and 3 . These results indicated that papaverine $(101.7 \pm 2.9, n=3)$, diltiazem $(101.0 \pm 3.6, n=3)$ and SNP $(95.8 \pm 8.5, n=3)$ had no effect on the caffeine-activated $\mathrm{Ca}$ releasing mechanism from the sarcoplasmic reticulum in skinned muscles.

\section{Discussion}

Changes in the membrane potential and membrane resistance of smooth muscles of vascular beds were not an essential factor in the suppression of the mechanical response by vasodilator agents. In the pig coronary artery, ACh produced contraction with no change in the membrane potential in the presence or absence of $[\mathrm{Ca}]_{\mathrm{o}}$. The $\mathrm{ACh}$-induced contraction is

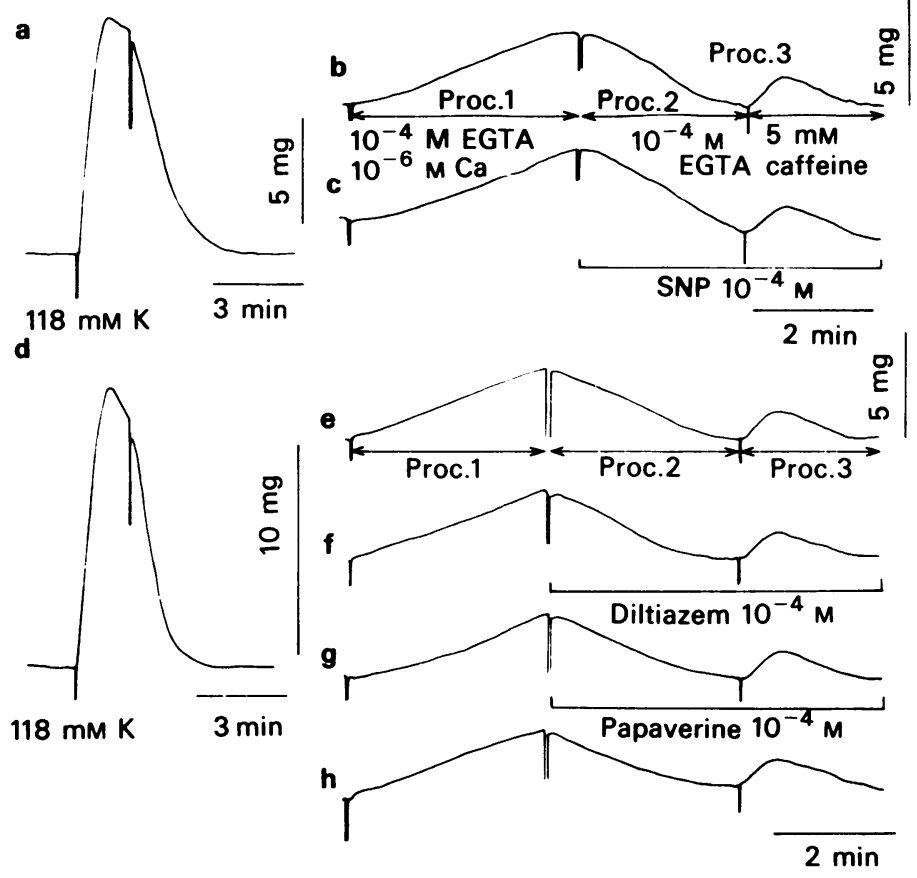

Figure 8 Effects of sodium nitroprusside $\left(10^{-4} \mathrm{M}\right)$, diltiazem $\left(10^{-4} \mathrm{M}\right)$ and papaverine $\left(10^{-4} \mathrm{M}\right)$ on the caffeineinduced contraction ( $5 \mathrm{mM}$ caffeine) in skinned muscles. (a-c) and (d-h) were recorded from different tissues. (a) and (d) Control. The $\mathrm{K}^{+}$-induced contraction evoked by $118 \mathrm{mM}[\mathrm{K}]_{\mathrm{o}}$ was the control. (b) and (e) Effects of $5 \mathrm{mM}$ caffeine on the $\mathrm{Ca}$ releasing site after Ca-loading of skinned muscles. Proc. 1: after the tissue was skinned, $10^{-6} \mathrm{M} \mathrm{Ca}$ with $10^{-4} \mathrm{M}$ EGTA were applied for $3 \mathrm{~min}$. Proc. 2: tissue was rinsed with solution containing $10^{-4} \mathrm{M}$ EGTA $(2.5$ $\mathrm{min}$ in (b) and (c) and $3 \mathrm{~min}$ in (e-h)). Proc. 3:5 mM caffeine was applied. SNP, diltiazem or papaverine was applied during Proc. 2 and Proc. 3. The sharp vertical deflections of the trace are washing artifacts. 
attributed to activation of muscarinic receptors distributed on the surface membrane which trigger $\mathrm{Ca}$ release from a storage site (Itoh et al., 1981a). Papaverine, diltiazem, SNP and NG (Ito et al., $1980 \mathrm{a}, \mathrm{b})$ suppressed the contraction evoked by $\mathrm{ACh}$, nonselectively at a concentration of $10^{-6} \mathrm{M}$. Papaverine, diltiazem and SNP did not affect caffeine-induced contraction in skinned muscles, i.e. these agents did not act directly on the same $\mathrm{Ca}$ releasing site as caffeine. It is possible that these vasodilator agents act on the muscarinic receptor and suppress the Ca releasing mechanism in the cell. The maximum amplitude of the $\mathrm{ACh}$-induced contraction was nearly twice the maximum amplitude of the caffeine-induced contraction in both Krebs and Cafree solution but both agents seem to release $\mathrm{Ca}$ from storage sites. Presumably the $\mathrm{Ca}$ releasing sites activated by caffeine and ACh differ (Itoh et al., 1981 a), hence, the possible action of vasodilator agents on the $\mathrm{Ca}$ releasing site for generation of the $\mathrm{ACh}$ induced contraction cannot be ruled out.

In contrast to the $\mathrm{ACh}$-induced contraction, the $\mathrm{K}^{+}$-induced contraction was abolished in $\mathrm{Ca}^{2+}$-free solution. Influx is the main source of $\mathrm{Ca}$ in the production of this contraction (Itoh et al., 1981a). Vasodilator agents used in the present experiments showed a variety of actions on the $\mathrm{K}^{+}$-induced contraction compared with those observed on the $\mathrm{ACh}$ induced contraction. In the presence of $10^{-5} \mathrm{M}$ papaverine, the $\mathrm{K}^{+}$-contraction was not suppressed although equimolar concentrations of diltiazem and SNP did reduce it. To produce the same degree of reduction as observed by treatment with diltiazem or SNP, over 10 times the concentration of papaverine was required.

$\mathrm{K}$-induced contraction was generated by activation of a voltage-dependent $\mathrm{Ca}$ influx, yet, these vasodilator agents did not suppress the depolarization induced by excess $[\mathrm{K}]_{\mathrm{o}}$, i.e. suppression of the Cainflux was not due to a lesser degree of depolarization of the membrane. Therefore, the agents presumably act on the Ca channel directly. Despite the smaller effect of papaverine observed on the $\mathrm{K}$-induced contraction as compared with other agents, the membrane properties under resting conditions were more affected by papaverine than by the other agents, for it hyperpolarized the membrane and increased the ionic conductance of the membrane to a greater extent than diltiazem or SNP, in equimolar concentrations. Therefore, the potency of papaverine on the resting membrane and on the voltage-dependent $\mathrm{Ca}$ channel differed.

A number of results point to the existence of two voltage-dependent $\mathrm{Ca}$ channels. The spike which could be evoked by outward current pulses in the presence of TEA, persisted in $\mathrm{NaCl}$-free solution without diminution in amplitude but was suppressed by treatment with $\mathrm{MnCl}_{2}$ (Itoh et al., 1981b). This spike, which is due to $\mathrm{Ca}$ inward current, was abolished by $10^{-5} \mathrm{M}$ diltiazem, and was suppressed by papaverine and SNP, while it was not affected by NG. The maximum amplitude of $\mathrm{K}$-induced contraction, which presumably reflects the maximum $\mathrm{Ca}$ influx, appeared at $-10 \mathrm{mV}$ during depolarization by $118 \mathrm{~mm}[\mathrm{~K}]_{\mathrm{o}}$, yet the Ca-spike evoked by outward current pulses was completely inactivated at $-10 \mathrm{mV}$. In the same concentration $\left(10^{-5} \mathrm{M}\right)$, at which diltiazem non-selectively suppressed $\mathrm{Ca}$ influx evoked by depolarization or spike, NG selectively suppressed the K-contraction. SNP suppressed the voltage-dependent $\mathrm{Ca}$ channel involved in the $\mathrm{K}$ contraction to a greater extent than the $\mathrm{Ca}$ channel for the spike generation, while papaverine had the opposite effect.

We used saponin-treated skinned muscles to investigate the $\mathrm{Ca}$ receptor of the contractile protein, and $\mathrm{Ca}$ accumulation and release from the storage sites. As a criterion to assess the success of the skinning, the amplitude of the maximum contraction evoked by $10^{-5} \mathrm{M} \mathrm{Ca}$ was compared with the $118 \mathrm{mM} \mathrm{K}$-induced contraction and only preparations showing a higher amplitude (over 120\%) were used. The pCa-tension relationship observed in the presence of papaverine, diltiazem or SNP was not affected. To confirm the action of these agents, the effects of chlorpromazine was used as this drug interacts with calmodulin in vascular tissue (Hidaka et al., 1980). Chlorpromazine suppressed the contraction evoked by $\mathrm{Ca}$ in skinned muscles. This means that the lack of effect of these vasodilator agents on the $\mathrm{pCa}$-tension relationship is not due to denaturation of the $\mathrm{Ca}$ receptor in the skinned muscles. The properties of the $\mathrm{Ca}$ receptor and $\mathrm{Ca}$ accumulation and releasing sites of coronary artery after skinning were similar to those observed in the guinea-pig mesenteric artery (Itoh $e t$ al., 1981b).

Tajima et al. (1980) described the effects of diltiazem on the pig coronary artery and our present results confirmed their observations, i.e. the contraction evoked by excess $[\mathrm{K}]_{\mathrm{o}}, \mathrm{ACh}$ and electrical depolarization were nonselectively suppressed by diltiazem. Similar results were also obtained in the case of the rabbit pulmonary and mesenteric arteries (Ito et al., 1979; Suzuki, Itoh \& Kuriyama, 1981).

In the guinea-pig mesenteric artery, $\mathrm{NaCl}$-free solution generated a contraction of an amplitude 0.8 times that of the contraction evoked by $118 \mathrm{mM}[\mathrm{K}]_{\mathrm{o}}$. This contraction was not affected by diltiazem (Suzuki et al., 1981). On the other hand, in the pig coronary artery, $\mathrm{NaCl}$-free solution did not generate contraction (Hirata, Itoh \& Kuriyama, 1981). Presumably, suppression of $\mathrm{Ca}$ influx by diltiazem is restricted only to the $\mathrm{Ca}$ ion moving through the $\mathrm{Ca}$ channel, because the $\mathrm{Ca}$ influx which is increased in 
$\mathrm{NaCl}$-free solution is postulated to be due to utilization of the Na channel (in the ear artery, Droogmans \& Casteels, 1979; in the mesenteric artery, Suzuki et al., 1981). Diltiazem may suppress the Ca channel, as has been postulated for the action of D600, nifedipine or verapamil (Grün, Fleckenstein \& Byon, 1971; Fleckenstein \& Byon, 1974; Fleckenstein, 1977; Golenhofen \& Hernstein, 1975; Casteels, 1980; Van Breemen, Aaronson, Loutzenhiser \& Meisheri, 1980).

Ito et al. (1979) found that SNP hyperpolarized the membrane in the rabbit pulmonary artery in concentrations over $10^{-8} \mathrm{M}$ and suppressed the spike evoked by outward current pulses in the presence of TEA. The contraction evoked by noradrenaline, excess $[\mathrm{K}]_{\mathrm{o}}$ or electrical depolarization was suppressed by SNP. This SNP action was more evident in the rabbit pulmonary artery and portal vein than in the pig coronary artery. However, effects of the drug on two different tissues from different species may not feasibly be compared. Golenhofen (1976) considered that with regard to visceral muscles, SNP mainly acts on the slow component of contraction and that the fast phasic component is less sensitive to this agent. Furthermore, Kreye \& Gross (1977) showed that this action of SNP is due to an increase in the $\mathrm{Cl}$ conductance of the membrane. Haeusler \& Thoren (1976) showed that SNP produced a concentrationdependent hyperpolarization.

Kreye, Baron, Lüth \& Schmidtgyak (1975) found that SNP acts as a potent inhibitor of excitationcontraction coupling in vascular smooth muscles, predominantly in tonic muscle, by interfering with both influx and intracellular activation of $\mathrm{Ca}$. Furthermore, SNP increased the rapidity of relaxation to more than twice the control value, even in the absence of extracellular $\mathrm{Ca}$, i.e. the inhibition of $\mathrm{Ca}$ influx is not a prerequisite for understanding the acceleration of the relaxing effect of SNP (Kreye \& Lüth, 1976).

Papaverine suppresses the contraction evoked in various visceral muscles. However, the effects of this compound on vascular smooth muscle are unknown. Kukovetz, Pöch, Wurm, Holzmann \& Paietta (1976) and Kukovetz, Wurm, Rinner, Holzmann \& Pöch (1977) found that papaverine possesses a vasodilator

\section{References}

ABE, Y. \& TOMITA, T. (1968). Cable properties of smooth muscle. J. Physiol., 196, 87-100.

CASTEELS, R. (1980). Electro- and pharmacomechanical coupling in vascular smooth muscle. Chest, 78, Suppl. 150-156.

DROOGMANS, G. \& CASTEELS, R. (1979). Sodium and calcium interaction in vascular smooth muscle cells of the rabbit ear artery. J. gen. Physiol., 74, 57-70. action on cattle and pig coronary arteries, in proportion to the amount of cyclic AMP formed as the result of inhibition of phosphodiesterase, and that this action is similar to that observed by treatment with theophylline or eupaverin. However, in the pig coronary artery, caffeine, a xanthine derivative, depolarized the membrane and increased the ionic conductance, yet suppressed the spike evoked by outward current pulse in the presence of TEA (Itoh et al., 1981a). Thus the action of papaverine or caffeine may not be solely due to inhibition of phosphodiesterase. In the guinea-pig taenia coli, Tashiro \& Tomita (1970) found that papaverine possesses an inhibitory action on smooth muscle cell and that its action was similar to that observed after treatment with isoprenaline; i.e. the membrane was slightly hyperpolarized with no change in the membrane resistance. The inhibitory action on the membrane activity is presumably due to suppression of automaticity of the cell. They also observed that the spike which evoked outward current pulses in the presence of papaverine was not affected, rather the resultant contraction was suppressed. The inhibitory action of papaverine on the membrane activity was not restored by the addition of excess $\mathrm{Ca}$ while the contraction was restored. Therefore, Tashiro \& Tomita (1970) concluded that papaverine may act on a Ca binding site at the plasma membrane. In smooth muscles of the pig coronary artery, the effects were much the same as observed in the guinea-pig taenia coli, although in physiological conditions, no spontaneous activity was generated in this tissue.

SNP is a nitrite compound, papaverine is a classical nonselective smooth muscle relaxant, and diltiazem is a Ca blocker. These agents produce vasodilatation in the pig coronary artery but responses of the muscle cells clearly differed with each agent. Further combined experiments with biochemical procedures and ion flux measurements may clarify their mechanisms of action.

This work was supported by the Ministry of Education and Welfare of Japan (54408, 544020), and Yamada Science Foundation. We also thank M. Ohara, Kyushu University, for reading the manuscript.

FLECKENSTEIN, A. (1977). Specific pharmacology of calcium in myocardium, cardiac pacemakers, and vascular smooth muscle. A. Rev. Pharmac. Tox., 17, 149-166.

FLECKENSTEIN, A. \& BYON, Y.K. (1974). Prevention by Ca-antagonistic compounds (verapamil, D-600) of coronary smooth muscle contractures due to treatment with cardiac glycosides. Naunyn-Schmiedebergs Arch. Pharmac., 282, Suppl. R. 20. 
GOLENHOFEN, K. (1976). Theory of $P$ and T systems for calcium activation in smooth muscle. In: Physiology of Smooth Muscle. ed. Bülbring, E. \& Shuba, M.F. pp. 197-202. New York: Raven Press.

GOLENHOFEN, K. \& HERNSTEIN, N. (1975). Differentiation of calcium activation mechanism in vascular smooth muscle by selective suppression with verapamil and D-600. Blood Vessels, 12, 21-37.

GRÜN, G., FLECKENSTEIN, A. \& BYON, Y.K. (1971). Caantagonism, a new principle of vasodilation. Proc. Int. Union Physiol. Sci., XXV Int. Congr., Munich IX, p. 221.

HARAFUJI, H. \& OGAWA, Y. (1980). Re-examination of the apparent binding constant of ethylene glycol bis

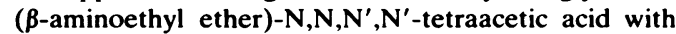
calcium around neutral pH. J. Biochem., 87, 1305-1312.

HÄEUSLER, G. \& THOREN, S. (1976). Pharmacology of vasoactive antihypertensives. In: Vascular Neuroeffector Mechanisms. ed. Bevan, J.A. pp. 232-241. Basel: S. Karger.

HIDAKA, H., YAMAKI, T., NAKA, M., TANAKA, T., HAYASHI, H. \& KOBAYASHI, R. (1980). Calciumregulated modulator protein interacting agents inhibit smooth muscle calcium-stimulated protein kinase and ATPase. Mol. Pharmac., 17, 66-72.

HIRATA, M., ITOH, T. \& KURIYAMA, H. (1981). Effects of external cations on calcium efflux from single cells of the guinea-pig taenia coli and porcine coronary artery. $J$. Physiol., 310, 321-336.

ITOH, T., KAJIWARA, M., KITAMURA, K. \& KURIYAMA, H. (1981a). Roles of stored Ca on mechanical responses in smooth muscle cells of the porcine coronary artery. $J$. Physiol. (in press).

ITO, Y., KITAMURA, K. \& KURIYAMA, H. (1979). Effects of acetylcholine and catecholamines on the smooth muscle cell of the porcine coronary artery. J. Physiol., 294, 595-611.

ITO, Y., KITAMURA, K. \& KURIYAMA, H. (1980a). Actions of nitroglycerine on the membrane and mechanical properties of smooth muscles of the coronary artery of the pig. Br. J. Pharmac., 70, 197-204.

ITO, Y., KITAMURA, K. \& KURIYAMA, H. (1980b). Nitroglycerine and catecholamine actions on smooth muscle cells of the canine coronary artery. J. Physiol. 309, 171-183.

ITOH, T., KURIYAMA, H. \& SUZUKI, H. (1981b). Excitation-contraction coupling in smooth muscle cells of the guinea-pig mesenteric artery. J. Physiol. (in press).

ITO, Y., SUZUKI, H. \& KURIYAMA, H. (1978). Effect of sodium nitroprusside on smooth muscle cells of rabbit pulmonary artery and portal vein. J. Pharmac. exp. Ther., 207, 1022-1031.

KREYE, V.A.W., BARON, G.D., LUTH, J.B. \& SCHMIDTAGYAK, H. (1975). Mode of action of sodium nitroprusside on vascular smooth muscle. NaunynSchmiedebergs Arch. Pharmac., 288, 381-402.

KREYE, V.A.W. \& GROSS, F. (1977). Nitroprusside. In: Handbook of Experimental Pharmacology, Vol. 39, Antihypertensive Agents. ed. Gross, F. pp. 418-430. New York: Springer-Verlag.

KREYE, V.A.W. \& LÜTH, J.B. (1976). Effect of sodium nitroprusside, temperature, and calcium withdrawal on the relaxation speed of vascular smooth muscle. In: Ionic Actions on Vascular Smooth Muscle. ed. Betz, E. pp. 145-149. Berlin, Heidelberg, New York: Springer.

KUKOVETZ, W.R., PÖCH, G., WURM, A., HOLZMANN, S. \& PAIETTA, E. (1976). Effect of phosphodiesterase inhibition on smooth muscle tone. In: Ionic Actions on Vascular Smooth Muscle. ed. Betz, E. pp. 124-134. Berlin, Heidelberg, New York: Springer.

KUKOVETZ, W.A., WURM, A., RINNER, I., HOLZMANN, S. \& PÖCH, G. (1977). Stimulation of adenylcyclase in coronary smooth muscle by adenosine ${ }^{+}$. In: ExcitationContraction Coupling in Smooth muscle. ed. Casteels, $\mathbf{R}$. pp. 399-406. Elsevier, North-Holland: Amsterdam.

MARTELL, A.E. \& SCHWARZENBACH, G. (1956). Adenosinphosphate und Triphosphate also Komplexbildner für Calcium und Magnesium. Helv. chim. Acta., 39, 653-666.

OHTSUKI, I., MAUZI, R.M., PALADE, G.E. \& JAMIESON, J.D. (1978). Entry of macromolecular tracers into cells fixed with low concentration of aldehydes. Biol. Cellulaire, 31, 119-126.

SAIDA, K. \& NONOMURA, Y. (1978). Characteristics of $\mathrm{Ca}^{2+}$ - and $\mathrm{Mg}^{2+}$-induced tension development in chemically skinned smooth muscle fibers. J. gen. Physiol., 72, $1-14$.

SUZUKI, H., ITOH, T. \& KURIYAMA, H. (1981). Effects of diltiazem on the mesenteric artery of guinea-pig. Jap. $J$. Pharmac., Suppl. 30 (in press).

TAJIMA, K., KANDA, S., KITAMURA, K., ITO, Y. \& KURIYAMA, H. (1980). Diltiazem actions on smooth muscle cells of the porcine coronary artery and on neuromuscular junctions of the guinea-pig vas deferens. Gen. pharmac., 11, 561-568.

TASHIRO, N. \& TOMITA, T. (1970). The effects of papaverine on the electrical and mechanical activity of the guinea-pig taenia coli. Br. J. Pharmac., 39, 608-618.

VAN BREEMEN, C., AARONSON, P., LOUTZENHISER, P. \& MEISHERI, K. (1980). $\mathrm{Ca}^{2+}$ movement in smooth muscle. Chest, 78, Suppl. 157-165. 